\title{
Hospitalization due to norovirus and genotypes of rotavirus in pediatric patients, state of Espírito Santo
}

\author{
Leandro Rua Ribeiro, Rafael Souto de Oliveira Giuberti, Débora Maria Pires Gonçalves Barreira, \\ Ketene Wernek Saick, José Paulo Gagliardi Leite', Marize Pereira Miagostovich', \\ Liliana Cruz Spano/ ${ }^{+}$
}

Nucleus of Infectious Diseases, Pathology Department, Health Science Center, Federal University of Espírito Santo, Av. Marechal Campos 1468, 29043-900 Vitória, ES, Brasil 'Laboratory of Comparative Virology, Instituto Oswaldo Cruz-Fiocruz, Rio de Janeiro, RJ, Brasil

Viruses are the leading cause for hospitalization due to gastroenteritis worldwide. Group A rotaviruses (RV) are the most prevalent and are assorted in glycoproteins $(G)$ and protease sensitive $(P)$ dual genotypes based on polymorphic genes that encode the external VP7 and VP4 capsid proteins, respectively. Noroviruses (NoV) have increasingly answered by sporadic gastroenteritis. This study aimed to determine the prevalence of NoV and RV in 68 hospitalized children, between July 2004 and November 2006, at a pediatric hospital in Vitória city, state of Espirito Santo, Southeastern Brazil. Nucleic acid was extracted from fecal suspension following the guanidine-silica procedure. Reverse transcriptase-polymerase chain reaction (RT-PCR) and polyacrylamide gel electrophoresis were employed for NoV and $R V$ detection, respectively. RV genotyping was accomplished using RT-PCR followed by heminested multiplex $P C R$ with specific primers for the most prevalent types of $G$ and $P$. Fecal samples were positive for $\mathrm{NoV}$ and $R V$ in 39.7\% (27/68) and 20.5\% (14/68), respectively and together were responsible for 60\% (41/68) of the cases. RV genotypes were: $50 \%$ G9P [8], 28.7\% G2P[4], 7.1\% G1P[8], G2P[8] and G?P[8]. Vomit was a prominent manifestation observed in $92 \%$ and $85 \%$ of the NoV and RV cases, respectively. The median hospitalization was 5 and 5.5 days for the patients infected with NoV and $R V$, respectively. The data showed that NoV prevailed over $R V$ and it also corroborated the emergence of $R V G 9$ genotype followed by G2P[4], reinforcing the need for $R V$ genotype surveillance.

Key words: noroviruses - group A rotaviruses - sporadic gastroenteritis - hospitalizations

Acute gastroenteritis remains a leading cause of morbidity and mortality worldwide, especially among those up to five years old. The global mortality is estimated at two million per year, mainly in developing countries (Okitsu-Negishi et al. 2004). Many infectious agents (bacteria, parasites and viruses) can be associated, but viruses are mainly responsible for endemic and epidemic gastroenteritis, mostly represented by group $\mathrm{A}$ rotaviruses (RV) and noroviruses (NoV). Although with low mortality in developed countries, gastroenteritis is one of the most common illnesses requiring hospitalization in an estimated one out of five cases, making this a serious public-health matter (Glass et al. 2006).

$\mathrm{RV}$, a member of Reoviridae family, is recognized as the most significant cause of diarrheic illness attacking children up to the age of three, worldwide (Glass et al. 2006). RVs are classified into seven groups (A-G) based on the VP6 intermediary capsid protein, of which three (A-C) are human pathogens; group A is responsible for 95\% of infections (Kapikian et al. 2001). The genome

Financial support: FACITEC, FUNCITEC, FAPES/MS/CNPq

+Corresponding author: 1spano@ndi.ufes.br

Received 1 November 2007

Accepted 18 February 2008 consists of 11 segments of dsRNA enclosed by three concentric capsids. The migration pattern in acrylamide gel electrophoresis serves to diagnose and permits inference of the RV group. The proteins VP4 and VP7 form external capsids and their respective genes classify group A RV in protease sensitive $(\mathrm{P})$ and glycoprotein (G) genotypes, respectively. Until now, 27 P genotypes (Martella et al. 2006) and $15 \mathrm{G}$ genotypes have been described, 11 and ten of P and G, respectively, are associated with human infection. The mostly commonly reported combinations are: G1P[8], G2P[4], G3P[8], G4P[8] and G9P[8] (Santos \& Hoshino 2005). However, uncommon genotypes or combinations are described throughout the world as well as in Brazil (Leite et al. 1996, Santos et al. 1998, Pietruchinski et al. 2006). Monovalent live oral $\mathrm{RV}$ vaccine $\left(\mathrm{G} 1 \mathrm{P}[8]\right.$, Rotarix $\left.{ }^{\mathrm{TM}}\right)$ recently introduced into the routine program of childhood immunization in Brazil, will potentially reduce the burden of severe diarrheic illness and hospital admission. However, continuous investigation of the group A RV genotypes is of extreme importance for surveillance of vaccine efficacy.

Norovirus, one of the two genera belonging to Caliciviridae family which causes human infection, is a small non-enveloped single strand RNA virus that requires special cell systems for in vitro replication (Straub et al. 2007). Human NoV strains belong to GI, GII or GIV genogroups from the five existing ones. NoVs are the major cause of epidemic gastroenteritis worldwide and are related to the consumption of food and water or aquatic 
recreational activities attacking persons of all ages (de Wit et al. 2003), as well as outbreaks in nurseries, hospitals, daycare centers and hotels (Gallimore et al. 2004, de Wit et al. 2007). However, since the 1990s, molecular procedures have recognized this virus as a common agent of sporadic self-limiting gastroenteritis (de Wit et al. 2001, Marshall et al. 2003, Oh et al. 2003).

The aim of this study was to determine the frequency of sporadic NoV and RV infection in children admitted to a hospital in Vitória, Espírito Santo. RV genotype was also accessed in the period before vaccine introduction.

\section{PATIENTS, MATERIALS AND METHODS}

From July 2004 to November 2006, 68 diarrheic stool samples were obtained (6 in 2004, 33 in 2005 and 29 in 2006) from 68 infants ( 63 under 4 and 5 between 4 and 12 years old), 64 of whom had been hospitalized with gastroenteritis. The patients were accessed at a pediatric hospital belonging to the UNIMED network, Centro Integrado de Assistência à Saúde (CIAS), in Vitória city, Southeastern Brazil. The samples, with free consent from the parents, were obtained after an average of 4.6 days of patient hospitalization. A questionnaire was applied for clinical and socio-demographic information and patient's records were accessed for complementary information (days of hospitalization, bacterial enteric pathogens). This study was approved by Ethical Research Committee from CIAS-UNIMED.

RNA was extracted using the guanidine isothiocyanate-silica method (Boom et al. 1990) from 10\% fecal suspension in $\mathrm{pH} 7.2$ Tris-calcium buffer $(0.01 \mathrm{M} / 0.0015 \mathrm{M})$. Biphasic polyacrylamide gel electrophoresis (PAGE) was performed to search for the 11 segments of RV dsRNA, silver stained, and the electropherotype was determinated (Herring et al. 1982, Pereira et al. 1983).

Complementary DNA (cDNA) was obtained in a reverse transcription reaction using $20 \mathrm{mU} \mathrm{pd}(\mathrm{N}) 6^{\mathrm{TM}}(\mathrm{Am}-$ ersham Bioscience, UK) hexanucleotide random primer (Iturriza-Gomara et al. 1999), after denaturation with dimethylsulfoxide for $7 \mathrm{~min}$ at $97^{\circ} \mathrm{C}$. The cDNA was then submitted to nucleic acid amplification for NoV detection in all samples and for RV genotypes of those that were positive on PAGE. To investigate NoV infection, polymerase chain reaction (PCR) was carried out with two primer pairs (MON 431/432 and MON 433-434) for the NoV polymerase gene region (Beuret et al. 2002), that amplify more than $90 \%$ of the strains from genogroups I and II (Blanton et al. 2006). Amplification protocol was according to Victoria et al. (2007). Consensus gene sequence related to external group A RV proteins was detected with a pair of consensus primers for VP7 (9con1-9con2) or VP4 (4con2-4con3) genes (Gentsch et al. 1992, Das et al. 1994). Reaction products of the first RV PCR were genotyped by heminested multiplex-PCR with two sets of specific primers for the G1-G5, G9 and $\mathrm{P}[4], \mathrm{P}[6], \mathrm{P}[8]$ and $\mathrm{P}[9]$ types described by Gentsch et al. (1992) and Das et al. (1994), with modifications by Leite et al. (1996). All the amplicons were carried out on $1.5 \%$ agarose gel stained with $0.5 \mu \mathrm{g} / \mathrm{ml}$ ethidium bromide and visualized with an Eagle-Eye-II ${ }^{\mathrm{TM}}$ imager using an UV transilluminator.

\section{RESULTS}

NoV and RV infection were detected in 39.7\% (27/68) and $20.5 \%(14 / 68)$ of the cases, respectively, showing that NoV and RV together affected $60 \%$ (41/68) of the hospitalized children. NoV was positive in $50 \%$ of the cases negative for RV. Viral gastroenteritis was responsible for hospital admission in $85 \%(23 / 27)$ of the NoV cases, the remaining $15 \%$ (4/27) were acquired in hospital. All cases positive for RV were the cause for hospitalization. No mixed infection was observed between the viruses or with enteropathogenic bacteria.

RV was detected only between June and August in all three years. NoV was detected between July and September 2005 and between May and July 2006, a period that corresponds to $89 \%$ of the strains obtained in this latter year. The majority (66.6\%) of NoV cases occurred in 2006.

Eighty five percent and $93 \%$ of the NoV and RV infections, respectively, occurred in children up to two years old (Table). One RV case occurred in a child between three and four years old. NoV infection occurred in two of the 5 children who were more than four years old.

Of the positive cases, diarrhea and vomit were observed in $96 \%$ and $100 \%$ of $\mathrm{NoV}$ and in $92.6 \%$ and $86 \%$ of RV infections, respectively. The median hospitalization was 5 and 5.5 days for NoV and RV, respectively.

All RV belonged to group A, based on the migration pattern on PAGE, ten of these showed a long and four a short profile. RV genotypes were distributed as shown: 50\% G9P[8] (7/14), 28.7\% G2P[4] (5/14), 7\% G1P[8], 7\%

TABLE

Distribution of Noroviruses (NoV) and group A Rotaviruses (RV) frequency according to age group, at a pediatric hospital in Vitória, Espírito Santo, July 2004 to November 2006

\begin{tabular}{|c|c|c|c|c|c|c|}
\hline \multirow{2}{*}{$\begin{array}{l}\text { Age } \\
\text { group }\end{array}$} & \multicolumn{3}{|c|}{$\operatorname{NoV}(\mathrm{n}=27)$} & \multicolumn{3}{|c|}{$\mathrm{RV}(\mathrm{n}=14)$} \\
\hline & Frequency & $\%$ & $\begin{array}{c}\text { Cumulative } \\
\%\end{array}$ & Frequency & $\%$ & $\begin{array}{c}\text { Cumulative } \\
\%\end{array}$ \\
\hline $0-1 \mathrm{y}$ & 14 & 51.9 & 51.9 & 5 & 35.7 & 35.7 \\
\hline$>1-2 y$ & 8 & 29.6 & 81.5 & 7 & 50.0 & 85.7 \\
\hline$>2-3 y$ & 2 & 7.4 & 88.9 & 1 & 7.1 & 92.9 \\
\hline$>3 y$ & 3 & 11.1 & 100 & 1 & 7.1 & 100 \\
\hline
\end{tabular}


G2P $[8]$ and 7\% G?P[8] (1/14 each). All short profiles were G2P[4] genotype. G9P [8] genotype was observed during 2004 and 2005, while G2P[4] appeared only in 2006.

\section{DISCUSSION}

Acute gastroenteritis is one of the most common illnesses and can be caused by several infectious agents (bacteria, parasites and virus), whose etiology and prevalence change among developed and developing countries. However, RV, NoV, astroviruses and enteric adenoviruses are pointed out as important morbidity agents, independent of improvements in basic sanitation and hygiene (Clark \& McKendrick 2004).

Besides RV, NoV that before was recognized as the major cause of epidemic nonbacterial gastroenteritis (Blanton et al. 2006), has now been shown to be an important agent of sporadic gastroenteritis worldwide $(\mathrm{Oh}$ et al. 2003, Kirkwood et al. 2005). However, little information is available concerning sporadic NoV infection in clinical or in hospitalized patients in developing countries (Gallimore et al. 2004, Borges et al. 2006, Soares et al. 2007, Victoria et al. 2007).

This work is the first report of NoV and RV in hospitalized children with gastroenteritis in Vitória, state of Espírito Santo and a high rate of NoV and RV infections were observed highlighting their importance in childhood hospitalization. NoV was found to be more important than RV in hospitalization-requiring admission due to gastroenteritis, at least in the period of study, on contrary to other reports that usually show NoV as the second cause after RV (Atmar \& Estes 2006).

The high prevalence of NoV reported here, contrasts with other reports elsewhere dealing with sporadic cases in hospitalized children, which vary from $5.4 \%$ to $30 \%$ in pediatric patients (Subekti et al. 2002, Oh et al. 2003, Hansman et al. 2004). Nevertheless, prevalence as high as $48.4 \%$ and $53 \%$ have also been related (Kirkwood \& Bishop 2001, Colomba et al. 2007). In Brazil, two studies conducted in hospitalized children revealed $8.6 \%$ of NoV infection in two cities in the West Central region (Borges et al. 2006); and a prevalence of $20 \%$ in Rio de Janeiro (Victoria et al. 2007). Considering gastroenteritis in cases negative for RV, we observed NoV in $50 \%$, which contrasts with the $15.4 \%$ observed by Soares et al. (2007) in Rio de Janeiro.

On the contrary to NoV studies in Brazil, RV has been researched for some time. The prevalence of RV in hospitalized Brazilian children varies according to similar studies from 14\% to 48\% (Cardoso et al. 2003, CarvalhoCosta et al. 2006) and points out the importance of RV as hospital admission due to gastroenteritis, although, in the population and in the period studied, NoV was more prevalent. Although the period of samples obtained was partially coincident with the beginning of RV vaccination in Brazil, we do not believe that it is responsible for the lower prevalence in relation to NoV, partially because the age of the immunized children at the end of the study in the hospital would have to be about five months old. No case of RV infection occurred in infants less than six months old and only one case appeared at six months, of a child that had not been vaccinated.
Few reports concerning NoV and $\mathrm{RV}$ co-infection are available and they refer to rates from $2.1 \%$ to $19 \%$ (Oh et al. 2003, Medici et al. 2004). Although the present study was conducted in a developing region, co-infection was expected but was not observed, probably due to the few cases obtained; however, $4 \%$ of dual infection was observed by this research group in children who attended the emergency sector of a pediatric reference hospital in our region (Spano and colleagues, unpublished observations), the same rate as recently reported in hospitalized children in Rio de Janeiro, Brazil (Victoria et al. 2007).

Most of the children in this study were up to four years old and in the others over four RV was not observed as gastroenteritis cause. As has been well established, $90 \%$ of group A RV infection occurs during the first three years of life, whereas $\mathrm{NoV}$ attacks individuals of all ages (Kapikian et al. 2001, Atmar \& Estes 2006). However, half of the NoV cases occurred up to one year old and most of them (81.5\%) up to two years old, similar to the previous report from Rio de Janeiro (Victoria et al. 2007).

The average number of hospitalization days for $\mathrm{NoV}$ and RV infections was similar for both in this study, close to five days, as also reported by Rockx et al. (2002) in a prospective study about the natural history of calicivirus infection. The duration of $\mathrm{NoV}$ infection was previously determined to be short (1-3 days); however, reports of sporadic cases have shown longer periods (Atmar \& Estes 2006). Thus, NoV-associated diseases can last longer than they were previously recognized. Some reports give further evidence that the duration of symptoms reduces with increasing age (Rockx et al. 2002). On the other hand, Lee et al. (2007) provides information on higher viral concentration with prolonged diarrhea ( $\geq 4$ days).

Vomit was a prominent clinical signal observed for both virus infections in $90 \%$ of the all cases. Clinical reports describe vomit as an important manifestation for both RV and NoV infection, but less than we observed (Estes et al. 2001, Kapikian et al. 2001, Rockx et al. 2002). While Rockx et al. (2002) described that vomit was less common in NoV-infected children aged $<1$ year $(59 \%), 85.7 \%$ of the patients in the present study, also infected with $\mathrm{NoV}$ at this same age group, presented vomit. Our results are also in contrast with those reported in children infected with NoV at a hospital in Rio de Janeiro that reported vomit in $33.3 \%$ of the cases (Victoria et al. 2007). According to Moreno-Espinosa et al. (2004) vomit occurs more frequently in children than diarrhea does once more in disagreement with our results. At present, there is no explanation for these data.

Although NoV is primarily transmitted by the fecaloral route, vomit carries the additional risk for nosocomial transmission through generation of infectious aerosol, an important airborne source of transmission (Marks et al. 2003). Four cases positive for NoV occurred in children admitted to the hospital for causes other than gastroenteritis, suggesting nosocomial transmission.

Most of the studies on seasonality describe winter 
peaks in NoV-associated outbreaks or sporadic cases (Fankhauser et al. 1998, Fretz 2005) and some reports, in spring and summer, varying according to the $\mathrm{NoV}$ genogroups (Marshall et al. 2003). Prevalence of $\mathrm{NoV}$ at the beginning of the dry season was previously observed in Vietnam (Hansman et al. 2004). In contrast to countries with a temperate climate, the region of the present study does not have a clear variation in temperature. According to meteorological data, $\mathrm{NoV}$ infections occur in a period with a lower rainfall, which is in agreement with the recently published data concerning the dry periods of the year in Rio de Janeiro, the same Southeastern region as ours (Victoria et al. 2007), while Soares et al. (2007) did not find any seasonal pattern in the same region in an eight year study. On the other hand, Borges et al. (2006) related seasonality in the period of higher humidity in the West Central region, sub-tropical zone Brazil. Therefore, these data denote that more studies are needed to better elucidate this subject.

$\mathrm{RV}$ cases coincided with dryer months and are similar to other studies in Southeastern Brazil (Araujo et al. 2002, Rosa e Silva et al. 2002, Carvalho-Costa et al. 2006). The seasonality related to group A RV infection is in winter and dry months, although this pattern does not happen uniformly in tropical countries (Kapikian et al. 2001).

Taking the group A RV genotypes into account, the epidemiologic importance of G9P[8] found in $43 \%$ of the cases must be emphasized, overcoming the classic G1-G4 genotypes. This data reinforces the emergence of G9 on the Brazilian scenario, described for the first time in Rio de Janeiro by two research groups (Araujo et al. 2001, Santos et al. 2001) and at present, considered one of the most frequent genotypes in Goiás, Salvador and Rio de Janeiro (Costa et al. 2004, Santos et al. 2005, Carvalho-Costa et al. 2006, Volotão et al. 2006).

Among RV strains, a short profile in PAGE was observed in $28 \%$ of the cases, all of them corresponding to the G2P[4] genotype, which was observed among the strains obtained during 2006 but not during 2004 and 2005. Furthermore, this genotype was not detected in a previous study realized by this same research group in children attended to in an emergency room between 2003-2004 (Spano and colleagues, unpublished observations). This fact points out the temporal fluctuation of RV circulation strains in consecutive years and in a same geographic area, as related in a review (Santos \& Hoshino 2005).

An extensive clinical assay conduced in Latin America, gave evidence of the protection conferred against the genotypes of group A RV observed here, with only a minor response to G2 (Linhares \& Villa 2006). Recently published results show the detection of the single G2P [4] genotype in vaccinated patients in Northern Brazil (Gurgel et al. 2007). It thus becomes clear that RV genotype surveillance is beyond doubt a somewhat pressing question in order to observe it as a gastroenteritis agent and its clinical severity as well as to evaluate the vaccine immunization efficacy.

In conclusion, the present results revealed that, during the period of study, NoV was more frequent than RV as the hospitalization cause due to gastroenteritis; a long period of hospitalization was observed not only for RV, but also for NoV infection; the occurrence of NoV and $\mathrm{RV}$ infection was mainly in the first two years of life, albeit NoV has been detected up to 12 years; prominent diarrhea and vomit was observed for both infections; RV genotype was represented mainly by G9 and followed by G2. It should be pointed out that there is a need to accomplish further studies on NoV and on genogroup determination, due to the scarce data on this subject in Brazil and to better determine the real impacts of this infection.

\section{REFERENCES}

Araujo IT, Ferreira MS, Fialho AM, Assis RM, Cruz CM, Rocha M, Leite JP 2001. Rotavirus genotypes P[4]G9, P[6]G9, and P[8]G9 in hospitalized children with acute gastroenteritis in Rio de Janeiro, Brazil. J Clin Microbiol 39: 1999-2001.

Araujo IT, Fialho AM, Assis RMS, Rocha M, Galvão M, Cruz CM, Ferreira MSR, Leite JPG 2002. Rotavirus strain diversity in Rio de Janeiro, Brazil: Characterization of VP4 and VP7 genotypes in hospitalized children. $J$ Trop Pediatr 48: 214-218.

Atmar RL, Estes MK 2006. The epidemiologic and clinical importance of norovirus infection. Gastroenterol Clin North Am 35: 275-290.

Beuret C, Kohler D, Baumgartner A, Luthi TM 2002. Norwalk-like virus sequences in mineral waters: one-year monitoring of three brands. Appl Environ Microbiol 68: 1925-1931.

Blanton LH, Adams SM, Beard RS, Wei G, Bulens SN, Widdowson MA, Glass RI, Monroe SS 2006. Molecular and epidemiologic trends of caliciviruses associated with outbreaks of acute gastroenteritis in the United States, 2000-2004. J Infect Dis 193: 413-421.

Boom R, Sol CJA, Salimans MMM, Jansen CL, Wertheim-van Dillen PME, Van der Noordaa J 1990. Rapid and simple method for purification of nucleic acids. J Clin Microbiol 28: 495-503.

Borges AM, Teixeira JM, Costa PS, Giugliano LG, Fiaccadori FS, Franco RC, Brito WM, Leite JP, Cardoso DD 2006. Detection of calicivirus from fecal samples from children with acute gastroenteritis in the West Central region of Brazil. Mem Inst Oswaldo Cruz 101: 721-724.

Cardoso DD, Soares CM, Dias e Souza MB, de Azevedo MS, Martins RM, Queiroz DA, de Brito WM, Munford V, Racz ML 2003. Epidemiological features of rotavirus infection in Goiania, Goias, Brazil, from 1986 to 2000. Mem Inst Oswaldo Cruz 98: 25-29.

Carvalho-Costa FA, Assis RM, Fialho AM, Bóia MN, Alves DP, Martins CM, Leite JP 2006. Detection and molecular characterization of group A rotavirus from hospitalized children in Rio de Janeiro, Brazil, 2004. Mem Inst Oswaldo Cruz 101: 291-294.

Clark B, McKendrick M 2004. A review of viral gastroenteritis. Curr Opin Infect Dis 17: 461-469.

Colomba C, Saporito L, Giammanco GM, De Grazia S, Ramirez S, Arista S, Titone L 2007. Norovirus and gastroenteritis in hospitalized children, Italy. Emerg Infect Dis 9: 1389-1391.

Costa PSS, Cardoso DDP, Grisi SJFE, Silva PA, Fiaccadoro F, Souza MB, Santos RA 2004. Rotavirus A infections and reinfections: genotyping and vaccine implications. J Pediatr (Rio J) 80: 119-122.

Das BK, Gentsch JR, Cicirello HG, Woods PA, Gupta A, Ramachandran M, Kumar R, Bhan MK, Glass RI 1994. Characterization of rotavirus strains from newborns in New Delhi, India. J Clin Microbiol 32: 1820-1822. 
de Wit MA, Koopmans MP, Kortbeek LM, Wannet WJ, Vinjé J, van Leudsden F, Bartelds AI, van Duynhoven YT 2001. Sensor, a population based cohort study on gastroenteritis in the Netherlands: incidence and etiology. Am J Epidemiol 154: 666-674.

de Wit MA, Koopmans MP, van Duynhoven YT 2003. Risk Factors for Norovirus, Sapporo-like Virus, ad Group A Rotavirus Gastroenteritis. Emerg Infect Dis 9: 1563-1570.

de Wit MA, Widdowson MA, Vennema H, de Bruin E, Fernandes T, Koopmans M 2007. Large outbreak of Norovirus: The baker who should have known better. $J$ Infect 55: 188-193.

Estes MK, Kang G, Zeng CQ, Crawford SE, Ciarlet M 2001. Pathogenesis of rotavirus gastroenteritis. Novartis Found Symp 238: 82-96.

Fankhauser RL, Noel JS, Monroe SS, Ando T, Glass RI 1998. Molecular epidemiology of "Norwalk-like viruses" in outbreaks of gastroenteritis in the United States. J Infect Dis 178: 1571-1578.

Fretz R 2005. How important is the Norovirus relationship to gastroenteritis. Wien Klin Wochenschr 117: 785-788.

Gallimore CI, Barreiros MAB, Brown DWG, Nascimento JP, Leite JPG 2004. Noroviruses associated with acute gastroenteritis in a children's day care facility in Rio de Janeiro, Brazil. Braz J Med Biol Res 37: 321-326.

Gentsch JR, Glass RI, Woods P, Gouvea V, Gorziglia M, Flores J, Das BK, Bhan MK 1992. Identification of group A rotavirus gene 4 types by polymerase chain reaction. J Clin Microbiol 30: 1365-1373.

Glass RI, Parashar UD, Bresee JS, Turcios R, Fischer TK, Widdowson MA, Jiang B, Gentsch JR 2006. Rotavirus vaccines: current prospects and future challenges. Lancet 368: 323-332.

Gurgel RQ, Cuevas LE, Vieira SCF, Barros VCF, Fontes PB, Salustino EF, Nakagomi T, Dove W, Cunliffe N, Hart CA 2007. Predominance of rotavirus $\mathrm{P}[4] \mathrm{G} 2$ in a vaccinated population, Brazil. Emerg Infect Dis 13: 1571-1573.

Hansman GS, Doan LT, Kguyen TA, Okitsu S, Katayama K, Ogawa S, Natori K, Takeda N, Kato Y, Nishio O, Noda M, Ushijima H 2004. Detection of norovirus and sapovirus infection among children with gastroenteritis in Ho Chi Minh City, Vietnam. Arch Virol 149: 1673-1688.

Herring AJ, Inglis NF, Ojeh CK, Snodgrass DR, Menzies JD 1982. Rapid diagnosis of rotavirus infection by direct detection of viral nucleic acid in silver-stained polyacrylamide gels. J Clin Microbiol 16: 473-477.

Iturriza-Gomara M, Green J, Brown DW, Desselberger U, Gray JJ 1999. Comparison of specific and random priming in the reverse transcriptase polymerase chain reaction for genotyping group A rotaviruses. J Virol Methods 78: 93-103.

Kapikian AZ, Hoshino Y, Chanock RM. 2001. Rotaviruses. In DM Knipe, RM Howley, DE Griffin, RA Lamb, MA Martin, B Roizman, SE Straus, Fields Virology, 4th ed., Lippincott, Willians and Wilkins, Philadelphia, p. 1787-1825.

Kirkwood CD, Bishop RF 2001. Molecular detection of human calicivirus in young children hospitalized with acute gastroenteritis in Melbourne, Australia, during 1999. J Clin Microbiol 39: 2722-2724.

Kirkwood CD, Clark R, Bogdanovic-Sakran N, Bishop RF 2005. A 5 -year study of the prevalence and genetic diversity of human caliciviruses associated to hospital in Melbourne, Australia (1998-2002). J Med Virol 77: 96-101.

Lee N, Chan MCW, Wong B, Choi KW, Sin W, Lui G, Chan PKS, Lai RWM, Cockram CS, Sung JJY, Leung WK 2007. Fecal viral concentration and diarrhea in norovirus gastroenteritis. Emerg Infect Dis 13: 1399-1401.
Leite JP, Alfieri AA, Woods PA, Glass RI, Gentsch JR 1996. Rotavirus G and $P$ types circulating in Brazil: characterization by RT-PCR, probe hybridization, and sequence analysis. Arch Virol 141: 2365-2374.

Linhares AC, Villa LL 2006. Vaccines against rotavirus and human papillomavirus (HPV). J Pediatr (Rio J) 82: 25-34.

Marks PJ, Vipond IB, Regan FM, Wedgwood K, Fey RE, Caul EO 2003. A school outbreak of Norwalk-like virus: evidence for airborne transmission. Epidemiol Infect 131: 727-736.

Marshall JA, Hellard ME, Sinclair MI, Fairley CK, Cox BJ, Catton MG, Kelly H, Wright PJ 2003. Incidence and Characteristics of Endemic Norwalk-Like Virus-Associated Gastroenteritis. J Med Virol 69: 568-578.

Martella V, Ciarlet M, Banyai K, Lorusso E, Cavalli A, Corrente M, Elia G, Arista S, Camero M, Desario C, Decaro N, Lavazza A, Buonavoglia C 2006. Identification of a novel VP4 genotype carried by a serotype G5 porcine rotavirus strain. Virology 346: 301-311.

Medici MC, Martinelli M, Arcangeletti MC, Pinardi F, De Conto F, Dodi I, Virdis R, Abelli LA, Aloisi A, Zerbini L, Valcavi P, Calderaro A, Bernasconi S, Izzi GC, Dettori G, Chezzi C 2004. Epidemiological aspects of human rotavirus infection in children hospitalized with acute gastroenteritis in an area of northern Ita1y. Acta Biomed 75: 100-106.

Moreno-Espinosa S, Farkas T, Jiang X 2004. Human caliciviruses and pediatric gastroenteritis. Semin Pediatr Infect Dis 15: 237-245.

Oh DY, Gaedicke G, Schreier E 2003. Viral agents of acute gastroenteritis in German children: prevalence and molecular diversity. J Med Virol 71: 82-93.

Okitsu-Negishi S, Nguyen TA, Phan TG, Ushima H 2004. Molecular epidemiology of viral gastroenteritis in Asia. Pediatr Int 46: 245-252.

Pereira HG, Azeredo RS, Leite JPG, Barth OM, Sutmoller F, de Farias V, Vidal MN 1983. Comparison of polyacrylamide gel electrophoresis (PAGE), immuno-electron microscopy (IEM) and enzyme immunoassay (EIA) for the rapid diagnosis of rotavirus infection in children. Mem Inst Oswaldo Cruz 78: 483-490.

Pietruchinski E, Benati F, Lauretti F, Kisielius J, Ueda M, Volotão EM, Soares CC, Hoshino Y, Linhares RE, Nozawa C, Santos N 2006. Rotavirus diarrhea in children and adults in a southern city of Brazil in 2003: distribution of G/P types and finding of a rare G12 strain. J Med Virol 8: 1241-1249.

Rockx B, De Wit M, Vennema H, Vinjé J, De Bruin E, Van Duynhoven Y, Koopmans M 2002. Natural history of human calicivirus infection: a prospective cohort study. Clin Infect Dis 35: 246-253.

Rosa e Silva ML, Pires de Carvalho I, Gouvea V 2002. 1998-1999 rotavirus seasons in Juiz de Fora, Minas Gerais, Brazil: detection of an unusual G3P[4] epidemic strain. J Clin Microbiol 40: 2837-2842.

Santos N, Hoshino Y 2005. Global distribution of rotavirus serotypes/ genotypes and its implication for the development and implementation of an effective rotavirus vaccine. Rev Med Virol 15: 29-56.

Santos N, Lima RC, Pereira CF, Gouvea V 1998. Detection of rotavirus types G8 and G10 among Brazilian children with diarrhea. J Clin Microbiol 36: 2727-2729.

Santos N, Volotão EM, Soares CC, Albuquerque MC, da Silva FM, de Carvalho TR, Pereira CF, Chizhikov V, Hoshino Y 2001. Rotavirus strains bearing genotype G9 or P[9] recovered from Brazilian children with diarrhea from 1997 to 1999. J Clin Microbiol 39: $1157-1160$.

Santos N, Volotão EM, Soares CC, Campos GS, Sardi SI, Hoshino Y 2005. Predominance of rotavirus genotype G9 during the 1999, 2000, and 2002 seasons among hospitalized children in the city of Salvador, Bahia, Brazil: implications for future vaccine strategies. J Clin Microbiol 43: 4064-4069. 
Soares CC, Santos N, Beard RS, Albuquerque MC, Maranhão AG, Rocha LN, Ramírez ML, Monroe SS, Glass RI, Gentsch J 2007. Norovirus detection and genotyping for chidren with gastroenteritis, Brazil. Emerg Infect Dis 13: 1244-1246.

Straub TM, Honer zu Bentrup K, Orosz-Coghlan P, Dohnalkova A, Mayer BK, Bartholomew RA, Valdez CO, Bruckner-Lea CJ, Gerba CP, Abbaszadegan M, Nickerson CA 2007. In vitro cell culture infectivity assay for human noroviruses. Emerg Infect Dis 13: 396-403.

Subekti DS, Tjaniadi P, Lesmana M, Simanjuntak C, Komalarini S, Digdowirogo H, Setiawan B, Corwin AL, Campbell JR, Porter
KR, Oyofo BA 2002. Characterization of Norwalk-like virus associated with gastroenteritis in Indonesia. J Med Virol 67: 253258.

Victoria M, Carvalho-Costa FA, Heinemann MB, Leite JP, Miagostovich M 2007. Prevalence and molecular epidemiology of noroviruses in hospitalized children with acute gastroenteritis in Rio de janeiro, Brazil, 2004. Pediatr Infect Dis J 26: 602-606.

Volotão EM, Soares CC, Maranhão AG, Rocha LN, Hoshino Y, Santos N 2006. Rotavirus surveillance in the city of Rio de Janeiro-Brazil during 2000-2004: detection of unusual strains with G8P[4] or G10P[9] specificities. J Med Virol 78: 263-272. 